\title{
Investigation and Analysis of the Shenyang local O2O Business Model
}

\author{
Cui Sun \\ School of Economic and Management \\ Shenyang Aerospace University \\ Shenyang, China
}

\author{
Zhu Linlin \\ School of Economic and Management \\ Shenyang Aerospace University \\ Shenyang, China
}

\begin{abstract}
O2O e-commerce model is a promising young e-commerce model derived from the traditional ecommerce model, it especially solves the store sales problem in service industry and commodity backlog problem of traditional business. After the rise of ecommerce in China, e-commerce got wide response of merchants in every field.. In order to provide consumers with better services, e-commerce trading patterns are changing: "Electronic Market + Logistics Distribution" $\rightarrow$ "Electronic Market + To Store Consumption", the intersection of online and offline are becoming reality by mobile and local experiences, so consumers can have both the convenience and benefit of online ordering and perfect experience of offline consumption. Today $\mathrm{O2O}$ business model has become the new favorite of the group buying and service, a variety of promotional means have also applied the $\mathrm{O2O}, \mathrm{O2O}$ is playing an increasingly large role in network marketing.
\end{abstract}

Keywords-O2O; Case Analysis; Business Model

\section{INTRODUCTION}

With the development of e-commerce technology, the traditional $\mathrm{B} 2 \mathrm{~B}, \mathrm{~B} 2 \mathrm{C}$ e-commerce model are no longer able to meet the actual needs of enterprises of all the fields, under the promotion of the social big wave, ecommerce platform update and APP new technology upgrade, the scale of a part of business area is small, competitiveness is not strong, in order to quickly develop, follow the traditional development way stepby-step is not enough. Limitations of traditional PC end has limited the development of e-commerce, and $\mathrm{O} 2 \mathrm{O}$ just makes use of the taking-along of mobile terminal, the uniqueness of user identity, the traceability of user's location and other characteristics to seize a number of potential improvised consumers.

Although there is considerable growth in China's online shopping market in recent years, the scale only accounted for $5.63 \%$ of the total retail amount of social consumer goods in 2011, the largest consumption market is still offline. E-commerce is now moving towards new fields. The service model of combination of online and offline has obvious advantages, it is not only conducive to the overall industry progress and to enhance customer service, but also conducive to improve industry and industry progress, $\mathrm{O} 2 \mathrm{O}$ are highly integrated and developed with local community field, the integration of the internet localization services will definitely form scale. To explore the integration of online economics and offline economics is inevitable tendency of e-commerce development. $\mathrm{O} 2 \mathrm{O}$ model has a broad development prospects. So studying Shenyang local $\mathrm{O} 2 \mathrm{O}$ business applications has great significance for the expansion of $\mathrm{O} 2 \mathrm{O}$ business theory and improvement of e-commerce implementation effect.

\section{DATA INVESTIGATION AND ANALYSIS OF THE SHENYANG LOCAL O2O DEVELOPMENT}

\section{A. The impact of domestic O2O business model on Shenyang commercial development}

$\mathrm{O} 2 \mathrm{O}$ this brand new e-commerce is opening brand new economic model for each size of businesses with its rapid response mechanism and resources coordination capacity of high efficiency and low cost. Under the influence of large domestic environment, $\mathrm{O} 2 \mathrm{O}$ business model has big impact for economic development in Shenyang. Currently, impacting factors of domestic $\mathrm{O} 2 \mathrm{O}$ business model on traditional business activities of Shenyang businesses include:

1)The invasion competition of new business models attacks the profitability of Shenyang traditional business model. From the fact that e-commerce begins the serious attack on traditional business, $\mathrm{O} 2 \mathrm{O}$ this new and innovative business model followed behind closely, it conducted a series of joint promotion effect on Shenyang small family style businesses like catering, tourism and service industry. In recent two years, the profit amount of medium-sized and small enterprises frequently rise, a large part is the application of the $\mathrm{O} 2 \mathrm{O}$ business model.

2)Shenyang local businesses are forced to think innovation. $\mathrm{O} 2 \mathrm{O}$ is survival exploration and innovation developed combining local characteristics. Local website or business model must keep in mind: innovation, which is combined with their own advantages. The biggest advantage of Shenyang merchants is their knowledge and familiarity of local market. $\mathrm{O} 2 \mathrm{O}$ online trading and offline experience mode provides brand new user experience model. We are familiar with local people, we are familiar with local 
businesses, we are familiar with local site business model, the perfect combination of the three only belongs to $\mathrm{O} 2 \mathrm{O}$.

3)Changing the consumers' consumption experience. $\mathrm{O} 2 \mathrm{O}$ can bring consumers the most authentic consumption experience. Real consumption experience is the biggest feature that $\mathrm{O} 2 \mathrm{O}$ model is suitable for local website development. In fact, hot group buying is just enough for us to get a glimpse. We order online and are busy enjoying ourselves by offline experience.

4)Prompting the symmetry of supply and demand information in Shenyang. O2O true interactive marketing can integrate with local businesses deeply. Each local business should know that customers are looking for business information, businesses are looking for customers. Yes, when the customer is finding a trustworthy decoration company, housekeeping company or a hairdresser, those good businesses may also be worried for finding customers. In the times we live, information is always so asymmetric. This asymmetry is the opportunity for $\mathrm{O} 2 \mathrm{O}$. Now that local businesses are looking for each other, then they should try to build this platform to provide this service

\section{B. Problems existing in the development of e- commerce in coal enterprises}

1) Deficiencies existing in current coal trading platforms in our country

The information service level is deficient in coal trading center. Although each large coal operation center would publicize trading information of different coals home and abroad on their own websites as well as relevant trend of its market survey report, it is still very difficult to establish an effective and practical coal trading market with information sharing and business collaboration according to these information since internal communication and collaboration are seriously deficient.

2) Problems existing in informatization construction of coal enterprises

Affected by traditional concept, coal enterprises in our country have backward management mechanism and irrational organizational structure. Due to the effect of long-term planned economy system, management system and management mode in coal enterprise are all very backward. Besides, the organizational structure in coal enterprises is pyramid-type vertical structure due to the influence of history and policies. Communications among each level are conducted from top to bottom vertically without any lateral relations. This

We can see the basic trading process of ecommerce in coal industry from figure $3-1$. The coal enterprise users make request for coal trading business, and then the request information will be delivered to trading center together with banking account by Internet; The trading center will search multiple appropriate coal manufacturing enterprises intellectually on the Internet by orders' need; After receiving procurement materials from the market, coal manufacturers will analyze and organizational structure has made enterprise and institute redundant with overlapping departments.

3) Problems existing in logistics supply system

In practice, logistics supply chain in coal industry is different from supply chains in other industries. The supply chain in coal industry is a very long industry chain, which is very complicated from coal origins to traders. In our country, although large coal enterprises possess their own coal logistics business, their operation focus is not coal logistics service, and coal transportation service and coal processing service they offered are not their operation focus, so service level in our country is far lower than that offered by other coal enterprises in the world.

\section{ANALYSIS ON THE DEVELOPMENT PATTERN OF E-COMMERCE IN COAL ENTERPRISES}

\section{A. The basic mode of e-commerce in coal enterprises}

At present, the development of e-commerce in coal industry in our country is mainly based on the establishment of two modes, which are e-commerce platform and third-party coal trading platform.

Now mature domestic coal trading markets with initial scales can be divided into the following three kinds, which are coal origins of manufacturing base, intermediate distributing place, and terminal users' consumption place.

The main coal origins are China (Taiyuan) Coal Trading Center, North (Inner Mongolia) Coal Trading Center, and Shanxi Coal Trading Center and so on.

Relevant domestic coal distributing places are mainly located in Tianjin Tianbao Dazong, Qinhuangdao Seaborne Coal Market and so on, which belong to middle and down harbors; while Zhenhai Coal Market, Guangzhou South China as well as Ningbo Coal Market, all of which belong to unloading ports.

Usually domestic major coal users centralize in central Shandong province, central China, Shenyang as well as coal trading center in Southwest of Guangxi and central China coal market.

Their operating methods are annual large-scale sales, daily common sales and special sales.

The development of e-commerce in coal enterprises is mainly based on B2B mode. As for coal enterprises, it means e-commerce between coal manufacturing enterprises and coal users by coal trading center. The advantage of B2B trading in coal enterprises lies in the high efficiency, neutrality as well as practicability. research the possibility of benefits by cooperating with the user, and manufacturers will submit their banking accounts and responding materials to information center once they reply buyers' intention, and then information management center will give certification on legal persons of both parties so as to complete capital circulation based on trade by submitting certification result to related banks that have been authorized by both parties. The trading information will be sent to 
trading center after completing transfer transaction, and then trading center will complete the trade and delivery by collaboration with industry and commerce, tax administration, customs as well as logistics and so on

\section{B. Collaborative e-commerce, the advanced mode of e-commerce in coal enterprises}

The concept of collaborative commerce which has been proposed by Gartner Group in 1999 is a commercial strategy stimulating cooperative partners of the same value chain with common commercial benefits, which is realized by information sharing in all stages of commercial periods. All members of valuable interest are combined together by their core competition so as to obtain profits by innovating new products or services.

With the application and expansion of new electronic technologies enabling in commercial field, development of collaborative e-commerce has been accelerated based on the application and support of ASP service union, driven by key technologies such as Gridcomputing, Object Management Group and Enterprise Application Integration and so on. The collaborative ecommerce has dual targets. On is to realize the ecommerce between enterprises and the business units of their cooperative partners, aiming to promote enterprise group activity efficiency and to realize real assets' complement by conducting various business cooperation within supply chain of various business units and cross-business units with change of business activity mode; on the other hand, it aims to build a newtype organization which is beneficial to information sharing and knowledge innovation among business units by breaking through obstacles impeding interorganization knowledge innovation and communication so as to reduce the organizational cost of realizing collaborative effect and stimulate intangible assets of enterprise group, leading to positive feedback effect of enterprise group's knowledge network, that is, innovation of collaborative effect for values net.

\section{THE ESTABLISHMENT OF COLLABORATIVE E- COMMERCE IN COAL ENTERPRISES}

\section{A. Internal collaboration in enterprises}

\section{1) ERP system}

Practical effect should be brought to enterprises if coal manufacturers want to implement informatization transformation. With the introduction of ERP system, raw coal procurement, production planning, manufactured coal sales, storage, coal washing as well as quality monitoring, finance, labor personnel management and office automation inside the enterprise can be linked together organically so that the production and sales process of an enterprise can be more scientific, standard and effective

\section{2) Customer Relationship Management}

Customer Relationship Management is a new-type management mechanism, aiming to improve the relationship between enterprises and customers. It aims to attract and maintain customers by more convenient and qualified services and to reduce cost by comprehensive management of business process. The emergence of CRM requires coal enterprises to transform their mode from "sell what we manufacture" to "manufacture what customer want". With the application of CRM, enterprises can collect, track and analyze information of each customer so as to master customers' need. By observing and analyzing the effect of customers' behaviors on enterprises' benefits, the relationship between enterprises and customers as well as enterprises' benefits can be better optimized.

\section{3) Other MIS system}

The advanced planning and scheduling optimizes and controls the overall logistics system with the application of binding theory, which requires to consider the availability of each coal product, determine the procurement and delivery date, conduct data optimization and analysis so as to make the best behavioral decision. Business Intelligence is to carry out business and management activities such as financial analysis, sales counting, market prediction, quality assessment, investment analysis and so on by applying decision-making analysis tools. As for electronic marketing system, it can make salesmen in coal enterprises sell their products easily and effectively on the internet with online payment and information exchanges, etc. With the development of e-commerce, new MIS systems will emerge constantly, so coal enterprises should choose the appropriate one according to their own features.

\section{B. External collaboration}

\section{1) Supply Chain Management system}

The coal resource-based enterprises determine their mining and production quantity by customers or market's need, which integrates customers and production units by logistics, capital flow and information flow. Supply Chain Management is to improve the efficiency and competitiveness of supply chain by employing a series of management methods and technologies with redesign of supply chain and selection of members so as to achieve a win-win result of all chain members

\section{2) Online websites}

The main purpose of building online websites is for online sales, which conduct marketing sales activities by network and electronic tools. Based on information flow, it can realize two-way communication crossing time and space and sell products with the new marketing environment, marketing interface and marketing means. Compared to traditional sales means, it has fair and free competitive environment which is convenient without any spatial and time limits with effective information exchanges and low cost. According to the status quo of coal enterprises, online websites for online sales mainly include the following aspects.

Information release of commodity. Information such as origin place, volatile, sulfur content, moisture, ash content, caloric value, quantity, delivery date, delivery place, delivery means and price of coal products should 
be released on the website regularly for users' reference. Those who have interest in them can communicate with manufacturers by commercial communication platform or other means.

Communication of commercial information. It does not mean rejecting traditional means for sales to conduct online sales, while actually it means new communication means and communication sites can be adopted for traditional sales. By the commercial communication platform, multiple sales ways can be conducted with communication so as to reach the purpose of convenience, fast and low cost.

Online auction sales. Auction sales is a new sales mode, an innovation of sales mode by coal enterprises, which can indeed realize the marketization of coal sales price. The traditional "coal ordering" sales mode is product of planned economy, which can neither reflect the real value of coal products by the price on ordering meeting nor the market price of coal that users locate.

The signature of electronic contract. The People's Republic of China Electronic Signature Law has been formally implemented since April 1st, 2005, which provides legal guarantee for the signature of electronic contract, and it also provides safety guarantee for signing electronic contract with the development of information technology. The two parties of the electronic contract should be given ID verification and certification in CA certification center which is safer than the traditional contract; besides, the employment of digital signature as well as the data and clauses in the electronic contract are safer than that in traditional contract as well.

3) Docked and integrated with industrial coal trading websites

At present, industrial coal trading websites are large-scale trading platforms like China (Taiyuan) Coal Trading Center, North (Inner Mongolia) Coal Trading Center, Shanxi Coal Trading Center, etc. By docking to and integrating with these trading platforms, enterprises can collect more information about supply and procurement regarding coal products, coal equipment and related industries with further information sharing of coals so as to gain more commercial chances. More importantly, allocation of resources in the whole industry can be more rational.

\section{Establish green logistics and transportation system for coal industry}

1) Further perfect logistics and transportation system in coal areas

The distribution of coal and mineral resources in China has distinctive regional characteristic with the major distributions in Shanxi province, Shanxi province, Inner Mongolia area of the South Sahara, Xinjiang Uygur Autonomous Region and so on. The places mentioned above have relatively more storage of coals in our country. We can give detailed market division of these coals by origin types so as to integrate regional logistics center and delivery center
We conclude from the exploration on development situation of coal materials circulation in China that it is the industrial development direction of coal materials circulation in China to establish professional coal materials circulation companies which can provide not only qualified coal logistics service but also professional coal production and intellectual coal delivery service. The establishment of professional coal logistics enterprises is beneficial to perfect logistics operation in coal industry as well as support the establishment of regional logistics system.

\section{CONCLUSION}

With the constant development of economy especially the network economy, e-commerce has become a guide for social development at present. With the application of e-commerce, coal enterprises can not only realize close communication with customers and cooperative partners, but they can also reduce production cost and raise benefits and even the core competitiveness of the whole enterprise. It is indeed a new way to develop e-commerce for coal enterprises in China since it has been popular due to the creation of a new-type commercial mode with rapid and effective operation as well as wide choices; besides, the operational platform that e-commerce relies on has certain specialty which makes the global development of e-commerce become the necessity. With the establishment of international rules for e-commerce, ecommerce will finally change people's life concept and life styles and will become the major commercial mode leading the development of global economy and trade in the next century.

However, the implementation of e-commerce can't be realized for all enterprises in a short time, instead, it should be conducted and implemented by informatization degree of coal enterprise itself and ecommerce degree based on enterprise's economic strength. The e-commerce development mode concluded in the paper has provided references for current manufacturers regarding implementation of ecommerce.

\section{REFERENCES}

[1] Shaokang, Main Means for Developing E-commerce in Coal Enterprises in Our Country[J]. China Mining, 2002, (5) $: 23-25$

[2] Wang Jianhui. Research on the E-commerce Development Based on Game Model[J].Research on Coal Economy, 2010, 117 (4) :61-66.

[3] Wang Huifang. Research on Countermeasures to E-commerce Development of Coal Industry in Our Country[J].Shanxi Taiyuan University of Technology, 2004,23-24.

[4] Stuart Feldman. " The Changing Face of ECommerce:Extending the Boundaries of the Possible" [J],IEEE INTERNET COMPUTING,2000, 162(3): 387-401.

[5] Yuxin. Research and Development of E-commerce System of Materials Procurement in Coal Industry[J]. Shandong: Shandong University of Science and Technology, 2006, 17-18.

[6] Xu Jingcai, Wanghua, Wenhu. Exploration on The Network Operation Mode of Coal Trad[J]. Mineral Safety and Environmental Protection, 2002, 152（3）:34-39 
[7] Wang Jianhui. Research on the Innovation of Coal Supply Chain Based on E-commerce[J]. Coal Technology, 2011, 209 (7) :2-7.

[8] Qian Dehong, Weiwei. Initial Exploration on Implementation of E-commerce for Coal Enterprises Logistics Management[J]. China Coal, 2002, 188 (3) :21-27.

[9] Guoke, Gaowei. Research on Coal Logistics Information Platform Based on E-commerce[J]. Modern Property,2011, 170 (8) :19-21.
[10] Li Aibin, Zhoumin, Bian Lili. Research on Green Coal Logistics System Based on Circular Economy[J]. China Mining,2007, 189 (4) : :45-49

[11] Hanchao. Research on Green Development Strategies in Coal Enterprises[J]Liaoning: Liaoning University of Engineering and Technology,2005, 13-14.

[12] James R.Kahn,Economic Approach to Environment and Natural Resources[J].South-Western,2005 , $163 \quad(5) \quad: 27-29$ 